\title{
A IMAGEM DA MULHER ESCRITORA NAS CRÔNICAS DE RACHEL DE QUEIROZ E IRENE LISBOA
}

\author{
Amanda Silva do Nascimento* \\ Iedo de Oliveira Paes*
}

\begin{abstract}
RESUMO: Este artigo se propõe a analisar o olhar crítico das cronistas Rachel de Queiroz e Irene Lisboa sobre a representação da mulher escritora, por meio de suas crônicas, não perdendo de vista o contexto vivenciado no Brasil e Portugal. Buscamos tratar de duas expressivas mulheres para a literatura de seus países e além deles; de um gênero não- canônico, a crônica, além de intentarmos encontrar as confluências e, ou divergências da representatividade feminina existente na escrita das duas escritoras, a partir de seus pontos de vistas e o processo de adjetivação. Utilizamos para o embasamento teórico conceitual do gênero literário Massaud Moisés (2007); Paula Lopes Cristina (2010); Davi Arrigucci (1987); Machado de Assis (1994) entre outros. Como aporte teórico a respeito de Rachel de Queiroz utilizamos Hollanda (2005); Eduardo Assis (2005) e para Irene Lisboa nos valemos de Paula Morão (1983), Óscar Lopes (1994) entre outros. Para analisar o processo de adjetivação nos valemos de Bechara (2009) e Murata (2008). Essas cronistas muito contribuíram para o campo literário, mas ainda permanecem pouco pesquisadas e por merecerem deferência, decidimos desenvolver esta pesquisa juntamente com o gênero pouco estimado pelas escolas e Academia.
\end{abstract}

PALAVRAS-CHAVE: Crônica; Irene Lisboa; mulher escritora; Rachel de Queiroz.

\section{Introdução}

Esta pesquisa é advinda de uma admiração pela Literatura de Autoria Feminina e pelo projeto literário desenvolvido pela Rachel de Queiroz e Irene Lisboa, escritoras que enxergavam a literatura como um espaço de denúncia social e de emancipação feminina.

Buscamos analisar qual era o ponto de vista dessas cronistas a respeito da mulher escritora na sociedade patriarcal do séc. 20, e como elas escancaravam seus sentimentos e indignações, por meio de um processo adjetival, pois como suscita Murata (2008) os adjetivos não servem apenas para classificar seres e objetos, mas para expressar as emoções e a subjetividade do escritor. Então vamos identificar a posição crítica das cronistas a partir da

\footnotetext{
* Mestranda em Estudos da Linguagem pela Universidade Federal Rural de Pernambuco (UFRPE).

** Doutor em Letras e Linguística pela Universidade Federal de Alagoas (Ufal). Professor da Universidade Federal Rural de Pernambuco (UFRPE).
} 
análise da crônica "A condição da mulher", de Rachel de Queiroz e "A mulher que escreve", de Irene Lisboa.

Primeiramente, apresentamos as cronistas pesquisadas, Rachel de Queiroz, uma grandiosa escritora brasileira, e que foi a primeira mulher a figurar na Academia Brasileira de Letras. Deixou um patrimônio literário que deve ser mais investigado, já que foi dona de uma arte literária que tanto colaborou para denunciar questões sociais em nosso país, e também para a luta feminina. Certamente, é responsável por obras que transcendem os tempos.

Já Irene Lisboa, foi uma escritora lisboeta, que divulgou, através de suas crônicas, a precária situação dos indivíduos que estavam na base da pirâmide social do século 20. Foi uma mulher de olhar revolucionário e devido ao seu espírito transgressor, foi mantida às sombras do cânone literário português. Para embasar essa discussão sobre a escritora Rachel de Queiroz nos valemos de Heloísa Buarque Hollanda (2005), Eduardo Assis (2005), Oliveira, Freire e Chaves (2012) e para Irene Lisboa utilizamos Paula Morão (1983), Óscar Lopes (1994), entre outros. Também contemplamos elementos sobre o feminismo no contexto brasileiro, para o que empregamos Constância Duarte (2009) e para o contexto português utilizamos Ana de Castro Osório (2015), Anne Cova e Antônio Costa Pinto (1997), Guimarães (1986) entre outros.

No segundo momento tratamos do conceito de crônica, um gênero pouco apetecido pela Academia, talvez por flertar entre o meio jornalístico e o literário. Muitas crônicas acabam por morrer ao terminar do dia; outras renascem nos livros e conseguem se eternizar. Um gênero que trata do corriqueiro, que muitas vezes não nos detemos. A crônica fala daquilo que muitas vezes não é notado, acende questionamentos; provoca reflexões e, mesmo assim, ainda não possui um espaço amplo nas escolas, e nos estudos acadêmicos. Ainda é entendido como um "um gênero menor", como afirma o eterno Antonio Candido (2003). Ao decorrer deste escrito também utilizamos Massaud Moisés (2007); Paula Lopes Cristina (2010); Davi Arrigucci (1987); Machado de Assis (1994) entre outros.

No terceiro tópico analisamos como é representada a mulher escritora nas crônicas já supracitadas, e como o processo adjetival colabora com nossa inquirição. Buscando 
refletir sobre como as personagens femininas escancaram a realidade de um contexto histórico e social vivenciado pelas escritoras estudadas, e como o gênero auxiliou para que as cronistas conseguissem expressar suas posições políticas e sociais promovendo, assim, uma certa subversão da conjuntura patriarcal vigente. Nosso intuito maior, mediante esta pesquisa de caráter bibliográfico, é destacar a produção literária deixada por duas grandiosas cronistas, bem como o gênero que também deve ser melhor averiguado.

Rachel de Queiroz: história de um nome

\author{
".... Louvo Rachel e, louvada \\ uma vez, louvo-a de novo. \\ Louvo sua inteligência. \\ e louvo o seu coração. \\ Qual maior? Sinceramente, \\ Meus amigos, não sei não [...]" \\ Manuel Bandeira
}

Rachel de Queiroz foi uma das mais consideráveis escritoras do século 20. O que ela nos deixou de riqueza literária é inquestionável e maior do que qualquer posição política controversa que ela tenha seguido ao longo da vida. Nasceu em Fortaleza, Ceará, em 17 de novembro de 1910, seus antepassados pelo lado materno, tinham ligações com a estirpe dos Alencar. Iniciou na vida literária, ainda muito jovem, aos 20 anos, com uma obra intitulada de $O$ Quinze, que é referência do período Regionalista de 1930 e que integra o grupo de clássicos do Brasil. Na época do lançamento, o livro possuía algo especial: era uma produção de autoria feminina. Uma obra com tanto primor e força de expressão, que houve quem não acreditasse ser uma obra de autoria feminina. Graciliano Ramos é um exemplo desse posicionamento:

o Quinze caiu de repente ali por meados de 30 e fez nos espíritos estragos maiores que o romance de José Américo, por ser livro de mulher e, o que realmente causava assombro, de mulher nova. Seria realmente mulher? Não acreditei. Lido o volume e visto o retrato no jornal, balancei a cabeça: Não há ninguém com este nome. É pilhéria. Uma garota assim fazer romance! Deve ser pseudônimo de sujeito barbado (RAMOS apud HOLLANDA, 2005, p. 15.) 
Por meio desse posicionamento, inferimos a situação da mulher na década de 1930. A capacidade intelectual feminina era algo que gerava dúvida, numa sociedade imersa em ideais patriarcais. Existia uma exclusão da mulher não apenas na Literatura, mas em outras áreas do conhecimento, que foram, dominantemente, destinadas aos homens, ocasionando a construção de um cânone literário masculino. Por muito tempo foi negado o acesso à cultura, à escrita, à leitura ao gênero feminino. Elas não tinham o direito a ler e escrever. Constância Duarte (2009) nos demonstra que,

a primeira legislação autorizando a abertura de escolas públicas femininas data de 1827, e até então as opções eram uns poucos conventos, que guardavam as meninas para o casamento, raras escolas particulares nas casas das professoras, ou o ensino individualizado, todos se ocupando apenas com as prendas domésticas (DUARTE, 2009, p. 153.)

A Literatura de Autoria Feminina se mescla ao Movimento Feminista, já que a mulher que desejava escrever, desenvolver atividades fora do seio doméstico, já indiciava uma transgressão aos princípios da sociedade patriarcal. A esse respeito, Zahidé Muzart explica que,

no século XIX, as mulheres que escreveram, que desejaram viver da pena, que desejaram ter uma profissão de escritoras, eram feministas, pois só o desejo de sair do fechamento doméstico já indicava uma cabeça pensante e um desejo de subversão. E eram ligadas à literatura. Então, na origem, a literatura feminina no Brasil esteve ligada sempre a um feminismo incipiente (MUZART apud DUARTE, 2009, p. 153.)

O movimento feminista pode ser dividido em quatro fases ou ondas e, em cada onda, as mulheres lutavam para ter direitos; para ir além dos serviços domésticos. Neste artigo nos detemos na terceira onda, porque foi nessa fase que a mulher começou a ser evidenciada na literatura e, entre essas mulheres, encontramos Rachel de Queiroz, escritora que fortificou a luta da emancipação feminina em nosso país. Eduardo Assis (2005) aponta:

a obra - e a vida - de Rachel de Queiroz figuram como índices precisos, espécie de marcos ou emblemas do processo 
de emancipação social da mulher brasileira no século XX [...] O fato de a maioridade social da mulher - e de todos os excluídos - ser entre os brasileiros pouco menos que uma utopia dá à obra de Rachel de Queiroz, e também à sua vida, o preciso relevo de fenômeno cuja caminhada teve seus passos acertados com o relógio da História. (ASSIS, 2005, p. 105.)

Referente às suas atividades no campo do jornalismo, foi através da crônica que ela desenvolveu a maior parte de suas produções, e conseguiu expor seu ponto de vista, críticas, memórias. Esse gênero a acompanhou nos suplementos de jornal por 77 anos, o que a tornou popular no ramo da escritura. Muitas de suas crônicas foram compiladas e transformadas em edições de livros; A donzela e a moura torta (1948) foi a primeira coletânea de crônicas. Além desse livro, ainda foram produzidos mais doze títulos com suas produções cronísticas.

Rachel de Queiroz compreendia o gênero crônica como algo bastante arqueável. Suas produções não seguiam um modelo estrutural limitado; muito pelo contrário, percebemos que seu trabalho com a crônica é diversificado, versando entre diálogos com o leitor a uma estrutura de quase-conto, desafiando o leitor que deseja separar a cronista da romancista. Como afirma Heloísa Buarque de Hollanda (2005) sobre a construção do gênero pela escritora:

a designação de crônica, extremamente maleável em Rachel, abriga da construção meticulosa de perfis a quase-contos de estrutura concisa, passando por relatos, pequenas histórias, reflexões ou simplesmente diálogos abertos com o leitor. O traço em comum desta experiência como cronista é o desafio que Rachel coloca para o leitor que queira estabelecer algum traço divisor entre a romancista, a cronista e a jornalista (HOLLANDA, 2005, p. 22.)

Uma escritora que nos deixou uma vasta produção de escritos, suas crônicas foram e continuam sendo significativas para compreendermos o passado e o presente. Muitas de suas produções como cronista já estão eternizadas nos livros e possuem significativas reflexões, inclusive sobre a condição da mulher. Escreveu romances como O quinz̧e (193); 
Caminho de Pedras (1937); As três Marias (1937); Dôra, Doralina (1975); Memorial de Maria Moura (1992). Produziu as peças teatrais: Lampião (1953) e A beata Maria do Egito (1958). Rachel de Queiroz recebeu valorosos prêmios pelas suas produções literárias, e fez do ato de escrever um caminho de crítica e denúncia social.

\section{Irene Lisboa: queres ouvir? Eu conto}

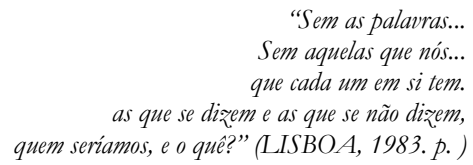

Irene do Céu Vieira Lisboa construiu obras valorosas para a Literatura Portuguesa, durante o século 20. Ela nasceu em 1892, no Concelho de Arruda dos Vinhos, Portugal. Dona de uma escrita singular, é uma expressiva autora do século XX, embora essa condição, por vezes, não seja reconhecida, sobretudo, por suas ideias contrárias ao Regime Salazarista. A ditadura comandada por Antônio de Oliveira Salazar, nasceu após um golpe militar que ocorreu em 28 de maio de 1926, sendo instituída em 1932. Portugal viveu imerso nesse regime por quarenta anos. Irene Lisboa, fez parte do grupo dos transgressores do sistema salazarista, e recebeu como consequência, o passaporte para às sombras do cânone literário português. A cronista estudou na Bélgica, na França e na Suíça; foi professora primária, depois inspetora orientadora, até ser afastada de suas funções; primeiro, por questões burocráticas, e, depois, por suas ideias transgressoras para o período. Foi uma mulher vanguardista, escreveu sobre a condição social, econômica e política de Portugal. Numa época, em que as mulheres não tinham espaço ativo na sociedade, Irene Lisboa se destacou como mulher e escritora; sobretudo, se buscarmos o que dizia o Código Civil do Estado Novo, regime que perdurou na maior parte da vida de Irene Lisboa.

O curioso critério de considerar os direitos da mulher como contrários ao bem da família teve como resultado o Código de Processo Civil de 1939 restabelecer o direito de o marido poder exigir o regresso da esposa ao domicílio conjugal, recorrendo à força se para tal fosse necessário. As mulheres da época nem queriam crer que a lei era tão cruel... (GUIMARÃES, 1986, p. 567.) 
Quer dizer, o direito da mulher teria que ir de encontro ao bem da família; ou seja, a mulher vivia enclausurada no espaço domiciliar, sendo impedida de desenvolver afazeres fora do lar; de conquistar sua própria independência. No sistema salazarista, a posição da mulher era o da submissão, do recato, por isso ela deveria seguir seu destino imposto "biologicamente" para ser mãe e esposa, e o esposo, o chefe da família, a pessoa que deveria ser seguida e obedecida, sem qualquer questionamento. $\mathrm{Na}$ época do Estado Novo, como afirma Anne Cova e Antônio Pinto (1997, p. 72), a mulher foi concebida para ser mãe, foi a "natureza" que assim decidiu. O Salazarismo acrescentou que deve ser uma mãe devota à pátria e ocupar-se do "governo doméstico".

O movimento feminista foi iniciado de forma tímida pelas mulheres da elite, todavia foi indispensável, para pensar em um país mais igualitário. Num país, onde $81,2 \%$ das mulheres em 1911, eram analfabetas, as associações feministas que lutavam pela igualdade de direitos entre homens e mulheres, decerto foi crucial para possibilitar mudanças. O movimento que mais perdurou em Portugal foi o Conselho Nacional das Mulheres Portuguesas, criado em 1914, e teve como influência a República Liberal, dirigido por Adelaide Cabete, uma médica ginecologista e ativista da causa feminista, anteriormente, havia contado com a participação de Ana de Castro Osório, esta autora do livro Mulheres Portuguesas (1905), uma obra pioneira na luta feminina, considerado o primeiro manifesto feminista de Portugal. A luta dessas mulheres, juntamente, com militantes como Albertina Paraíso, Cláudia de Campos e outras que se envolveram e colaboraram com o desenvolvimento de grupos e associações femininas foi relevante para a transformação da situação da mulher em Portugal.

Irene Lisboa também foi uma marcante figura na luta pela causa feminina, ela integrou o Movimento de Unidade Democrática (MUD), um grupo criado em 8 de outubro de 1945, e que tinha o objetivo de fazer oposição à Ditadura Salazarista. Usou pseudônimos como "João Falco" e "Maria Moira". Dentre suas obras encontramos: Um dia e outro dia: diário de uma mulher (1936), Outono bavias de vir latente triste (1937); Solidão: notas do punbo de uma mulher (1939); Começa uma vida (1940); Esta cidade! (1942); Apontamentos (1943); Uma mão cheia de nada outra de coisa nenbuma (1955); O pouco e o muito: crónica urbana (1956); Voltar atrás para 
quê? (1956); entre outras. A obra ireniana se volta para o autobiográfico, contos infantis e o comum existir, a vida das pessoas simples, que compõem a base da pirâmide social. Com uma escrita desapegada da forma e de classificações limitadas, Irene buscava construir obras intimistas. Para ela, o mais importante era o ato da escrita, e não o gênero no qual estava escrevendo, por isso, é dona de uma produção literária vasta e de escritos fragmentados, o que podemos comprovar até mesmo pelos títulos de suas composições literárias. Segundo Paula Morão (2007),

ora, o que lemos em Irene vai numa outra direcção, que toda a sua obra virá a seguir: na poesia como na prosa, não lhe interessam essas categorias estabelecidas, antes procurando sempre um estilo e formas próprias. De facto, Irene procede sempre por tentativas, por pesquisa sucessiva de um estilo e de uma voz, e por isso o que escreve é fragmentário, aparentemente incompleto, trabalhando sobre formas breves. Por isso se interessa pelo poema, mas adverte, ao abrir Outono havias de vir: "Ao que vos parecer verso chamai verso e ao resto chamai prosa” (MORÃO, 2007, p. 4.)

Diante do que inferimos, o mais relevante para sua produção literária era a profundidade do que escrevia; era sua própria forma de passar para o papel o sentimentalismo e a criticidade. A cronista seguiu os ideais presencistas, um movimento literário que surgiu em Portugal no ano de 1927, na cidade de Coimbra com a revista Presença, sob a coordenação de Branquinho da Fonseca, João Gaspar Simões e José Régio. Irene tinha uma escrita carregada de simplicidade, brevidade e singularidade, o que nos leva a pensar que sua obra nunca está findada, que suas histórias sempre podem ter uma continuação ou que elas estão, realmente, ocorrendo em alguma região de Portugal. Há um valor às coisas que são vistas como insignificantes.

Salta bem aos olhos que o seu focus final incide sobre o que, vendo bem as coisas importa, tudo aquilo que, de modo "insignificante", "sem valor", "sem interesse", "morto" ou "nulo" [...] A evidência existencial primária é a do banal ou insignificante quotidiano. " O existir, o comum existir não se pode negar. Nem invalidar (LOPES, 1994, p. 9-10.) 
Certamente, Irene Lisboa construiu uma arte viva, ao nos levar a refletir sobre o nosso comum viver. A escritora faleceu em Lisboa, no ano de 1958, porém a sua obra permanecerá viva, sobrevivendo aos regimes totalitários; transcendendo os tempos e as fronteiras portuguesas.

\section{Gênero Crônica: amiga da verdade e da poesia}

"Isto de se começar uma crônica... parece às vezes difícil, mas é como começar qualquer outra coisa. Começar é sempre irromper; dar de passo; encetar, abrir, desfechar, etc., etc." (LISBOA, 1983, p. 234.)

A crônica é um gênero que se vincula a efemeridade dos dias, aos detalhes do cotidiano, que muitas vezes passam despercebidos, porém o cronista consegue captar e tornar esses pequenos lapsos do dia, em narrativa. É um gênero que transita entre o meio jornalístico e o literário. É a poeticidade do jornal.

"Crônica” nasce do grego chronikós, relacionado ao tempo (chrónos), pelo latim temos o vocábulo "chronica". Nasceu na Europa medieval e renascentista, está associada à História, visto que era construída de maneira cronológica e tinha a função de relatar os feitos heroicos ou a vida dos reis e clero. Segundo Paula Cristina Lopes (2010) no excerto a seguir:

a crónica abrangia, pois, a vida ou reinado de um monarca, seus sucessos político-militares, ou a vida de corporações religiosas e de alguns dos seus membros mais ilustres (Crónica da Ordem dos Frades Menores). A narração é objetiva, serve-se do diálogo, aproxima-se à forma do conto (LOPES, 2010, p. 3.)

A incumbência dos cronistas era descrever a vida dos monarcas e a classe clerical; isto é, os indivíduos que constituíam a elite dos reinos portugueses eram os principais personagens na crônica histórica. Consoante a Moisés (2007), situada entre os anais e a história, limitava-se a registrar os eventos sem aprofundar-lhes as causas ou tentar interpretá-los. Ainda segundo o pesquisador, foi no século XIX, que a crônica se desprendeu da História e passou a ter uma implicação literária.

É em 1799 que o seu aparecimento ocorre, mercê dos fenil-

letons dados à estampa por Julien-Louis Geoffroy no Journal 
de Débats, que se publicava em Paris. Fazendo a crítica diária da atividade dramática, esse professor de retórica na verdade cultivava uma forma ainda embrionária da crônica, evidente no fato de reunir os artigos em seis volumes, sob o título de Cours de Littérature Dramatique (1819 - 1820). Apesar de tudo, encontrou numerosos imitadores, inclusive neste lado do Atlântico, surgidos após 1836 e que traduziam o termo francês por "folhetim" (MÓISES, 2007, p. 102.)

Ou seja, o trabalho principiante do professor francês com a crônica foi significativo para a evolução e divulgação do gênero, até mesmo para este lado do Atlântico, ganhando a simpatia de diversos escritores em nosso país. Paula Lopes Cristina (2010) afirma que

reza a história que o inglês Joseph Addison e o irlandês Richard Steele [fundador dos jornais literários The Tatler (1709) e The Spectator (1711)] foram os primeiros cultores do género, elevando-o à perfeição de texto literário publicado na imprensa. Note-se ainda que, no século XIX, a crónica literária, como hoje a conhecemos, designava-se "folhetim" (LOPES, 2010, p. 4.)

Portugal é outro país que aderiu à crônica-folhetim. No Distrito de Évora (1867), Eça de Queirós produziu uma crônica metalinguística, sobre o espaço ocupado pela crônica não só no jornal, mas em nossas vidas, e também relatou a respeito de toda a sua flexibilidade, enquanto gênero.

A crónica é como estes rapazes que não têm morada sua e que vivem no quarto de seus amigos, que entram com um cheiro de primavera, alegres, folgazões, dançando, que nos abraçam, que nos empurram, que nos falam de tudo, que se apropriam do nosso papel, do nosso colarinho, da nossa navalha de barba, que nos maçam, que nos fatigam mesmo e, quando se vão embora, nos deixam cheios de saudade (QUEIRÓS apud LOPES, 2010, p. 4.)

Entendemos que para o escritor português, Eça de Queirós a crônica não tem um local próprio para a sua divulgação. Chega com rapidez, pede um lugarzinho no jornal, deixa sua essência de poesia; ao mesmo tempo nos ensina a valorizar as coisas simples, efêmeras da vida, e se despede, deixando no espaço questionamentos e reflexões sobre a 
sociedade. A crônica nos dá um “tapa”, para acordarmos para ao que nos cerca; mas ela também nos "beija" com a sua poeticidade.

Antonio Candido reitera que foi na década de 30, que a crônica se consolidou em nossas terras, adquirindo aspectos brasilianos. Nessa década se destacaram: Mário de Andrade; Manuel Bandeira; Carlos Drummond de Andrade e Rubem Braga, este um escritor que se dedicou quase, exclusivamente, à crônica. Apesar de ser escrita por distintos escritores da Literatura Nacional, a crônica não é vista como um grande gênero:

a crônica não é um gênero maior. Não se imagina uma literatura feita de grandes cronistas, que lhe dessem o brilho universal dos grandes romancistas, dramaturgos e poetas. Nem se pensaria em atribuir o Prêmio Nobel a um cronista, por melhor que fosse. Portanto, parece que a crônica é um gênero menor. Graças a Deus - seria o caso de dizer, porque sendo assim ela fica perto de nós (CANDIDO, 2003, p. 89.)

Em outras palavras, para Candido a crônica é um gênero menor, porque não há um reconhecimento de sua importância na construção da identidade do escritor, além de ser um gênero pouco estudado pela Academia. Mas, é uma graça de Deus, que seja encarado como um gênero "menor", posto que é exatamente isso que a aproxima de nós, de nossos momentos rotineiros, humanizando quase sem querer. Conforme Afrânio Coutinho (2007), "a crônica é um gênero que faz fronteira entre a história e a vida cotidiana; para ele, a desordem provocada em torno do conceito do gênero é advinda do fato dela estar onde não deveria: nos livros e revistas". Quer dizer, para Coutinho é o local em que a crônica está posta que provoca esse desalinho de conceitos e classificações. Para Massaud Moises (2007):

o cronista pretende-se não o repórter, mas o poeta ou o ficcionista do cotidiano, desentranhar do acontecimento sua porção imanente de fantasia. Aliás, como procede todo autor de ficção, com a diferença de que o cronista reage de imediato ao acontecimento, sem deixar que o tempo lhe filtre as impurezas ou lhe confira as dimensões de mito, horizonte ambicionado por todo ficcionista de lei (MOISÉS, 2007, p. 105.) 
O cronista procura nas páginas dos jornais o material para embasar suas crônicas de forma poética e ficcional. Compreendemos que o gênero é uma maneira de discorrer a respeito da realidade de forma ficcional, ou o mundo real transportado para o campo literário. Como bem diz Candido (2003, p. 89), "a crônica auxilia a estabelecer e reestabelecer a dimensão das coisas e das pessoas, é amiga da verdade e da poesia”. Aproxima-se, assim, da nossa vida, de nossa forma de ser e agir sobre o mundo. Assis (1994):

há um meio certo de começar a crônica por uma trivialidade. É dizer: Que calor! Que desenfreado calor! Diz-se isto, agitando as pontas do lenço, bufando como um touro, ou simplesmente sacudindo a sobrecasaca. Resvala-se do calor aos fenômenos atmosféricos, fazem-se algumas conjeturas acerca do sol e da lua, outras sobre a febre amarela, mandase um suspiro a Petrópolis, e La glace est rompue; está começada a crônica (ASSIS, 1994, p. 13.)

No que concerne aos aspectos do gênero, notamos que é um gênero de curta extensão, envolvido por uma subjetividade, e mesmo quando o cronista não retrata uma situação pessoal, é visível a sua posição diante da circunstância. Massaud Moisés (2007) descreve a crônica como,

[...] um texto curto, de meia coluna de jornal ou de página de revista. [...] A brevidade reflete, e a um só tempo determina, as outras marcas da crónica. A subjetividade é a mais relevante de todas. $\mathrm{Na}$ crónica, o foco narrativo situa-se na primeira pessoa do singular; mesmo quando o "não-eu" avulta por encerrar um acontecimento de monta, o "eu” está presente de forma direta ou na transmissão do acontecimento segundo sua visão pessoal (MOISÉS, 2007, p. 116.)

Isto é, reforçamos as especificidades que norteiam a crônica, que é transpassada pela subjetividade do escritor (a), visto que o cronista relatará a circunstância a seu modo, guiado por seu ponto de vista, ideologias, todavia numa linguagem clara, direta, para que seja entendido por todos os apreciadores do jornal. É um texto breve, uma vez que está incorporado em uma página de jornal. Um gênero que possibilita uma liberdade aos cronistas, porque eles podem fugir dos padrões conceituais que, frequentemente, seguem os 
outros gêneros; possui uma elasticidade, uma maleabilidade. Talvez seja, justamente, essa liberdade que distancie a crônica dos estudos acadêmicos. A crônica ultrapassa as barreiras da efemeridade, quando é inserida nos livros, saindo da finitude do jornal para se eternizar na literatura.

\section{Análise das crônicas}

\subsection{A mulher que escreve}

$\mathrm{Na}$ crônica denominada "A mulher que escreve", de Irene Lisboa, percebemos uma certa crítica aos valores impostos à mulher do século 20 , época em que a mulher era jogada a inferioridade e submissão, destinada a resignação e cuidado do lar, consequentemente, era subestimada em sua intelectualidade. O gênero feminino possuía até a primeira metade do século anterior, um destino projetado por terceiros; um destino que a afastava do mundo literário, e de qualquer atividade externa. Sua função social era cuidar da família e obedecer aos desmandos do esposo. Não existia uma vida considerada "decente" para a mulher que se atrevesse burlar os valores fundamentados por dogmas sobretudo, religiosos. Vamos notar essa construção do espaço feminino, a partir de a análise dos adjetivos que, consoante a Murata (2008, p. 296), "constitui a manifestação privilegiada da subjetividade: classifica os objetos e seres no mundo e presentifica as reações emocionais do escritor/falante ante as coisas e os acontecimentos". Já para Bechara (2009, p. 121) “é a classe de lexema que se caracteriza por constituir a delimitação, isto é, por caracterizar as possibilidades designativas do substantivo, orientando delimitativamente a referência a uma parte ou a um aspecto do denotado". E das locuções, que ainda segundo Bechara (2009, p. 123) "é a expressão formada de preposição + substantivo ou equivalente com função de adjetivo, que são capazes de expor o grau de ironia". Percebemos um tom irônico em passagens como: "uma mulher pode bem escrever para se distrair. E até para provar que é inteligente! Há famílias que se honram com isso! Com os dotes chamados masculinos das mulheres" (LISBOA, 1983, p. 208). Isto é, uma mulher poderia desenvolver a escrita, o que provaria à sociedade e sua própria família, que ela tem capacidade intelectual, nesse período, qualidade ainda atrelada apenas aos homens. Ela pode escrever como passatempo, divertimento, mas não 
pode esperar qualquer tipo de reconhecimento literário. A mulher que tentava escrever era vista como curiosa, bisbilhoteira, porque a sua posição social era cuidando dos afazeres domésticos.

Mediante a análise do trecho a seguir, notamos a importância das escolhas lexicais de Lisboa (1983, p. 208) “Todos acham que, sim senhor, uma mulher escrever é engraşado, é curioso, é mesmo admissivel “ (grifos nossos). Ao que nos parece a utilização dos vocábulos destacados, demonstram uma certa indignação por parte da escritora, diante da situação em que se encontra a mulher escritora, no século 20. Depreendemos que a escrita de autoria feminina era considerada "engraçada", servindo como chacota, pois parte de alguém curioso, sem deter os conhecimentos técnicos necessários para exercer a arte da escrita. Além de ser considerada uma escrita apenas suportável. De acordo com Murata (2008, p. 297), “Tradicionalmente os adjetivos são divididos em dois grupos: o dos objetivos, os que possuem função descritiva ou classificadora; e o dos subjetivos, os que apresentam julgamento de valor, próprio de cada enunciador”. Essa composição lexical não foi escolhida ingenuamente, toda construção linguística advém de um local de fala, representando o ponto de vista do indivíduo, que no caso da cronista Irene Lisboa, é detectado um descontentamento em relação ao trato da sociedade em relação às mulheres escritoras. Observamos que ela descreve a maneira como é encarada a escrita de autoria feminina na sociedade, o que se configura como adjetivos objetivos, como supracitados. Os adjetivos auxiliam no desenvolvimento da narrativa, especialmente para o escritor alcançar seu intuito maior, que neste caso é sensibilizar o leitor sobre a condição da mulher numa sociedade patriarcal. Já no excerto a seguir da crônica, esse posicionamento crítico e seu sentimento de descontentamento ficam mais evidentes:

mas... Como a pena, a arte literária das mulheres, aos olhos de muitos homens, se confunde ainda com a do crochet, com os instrumentos de fazer passar o tempo, o que elas escrevem é sempre tacitamente irrespeitável. Frivolidades! Nunca coisas que detenham os espíritos sérios, e muito menos de propaganda, de expansão (LISBOA, 1983, p. 208, grifos nossos.)

A partir de a observância das escolhas dos lexemas, principalmente, relacionado às locuções adjetivas, refletimos sobre como são úteis para que a escritora consiga explanar 
sua posição crítica. Além de identificarmos o adjetivo objetivo "frivolidades" e os subjetivos: "tacitamente irrespeitável”; “espíritos sérios”; "propaganda de expansão", uma vez que retratam a situação vivenciada pelas mulheres com um tom mais pessoal, de indignação. Irene Lisboa compartilha através de sua composição cronística o seu ponto de vista, criticando e expondo as mazelas sociais, e leva os leitores de suas crônicas a refletirem e questionarem o status quo.

A crônica interligada à Literatura, promove a análise e reflexão de assuntos atuais do escopo social. É o dia a dia atravessado pelo lirismo. A cronista utiliza os vocábulos “tacitamente irrespeitável”, um advérbio que transforma e expande o sentido do adjetivo “irrespeitável”, com o intuito de corroborar a inexistência de respeito à escrita de autoria feminina, não é apenas "irrespeitável”; é, "tacitamente irrespeitável”. Ela se vale da construção "frivolidades" para realçar essa visão da sociedade em torno do fazer literário da mulher, ou seja, era algo enxergado como inútil e de pouco valor. Outra construção que nos detemos foi: "nunca coisas que detenham os espíritos sérios" a escrita de autoria feminina não era visto como algo que tratasse de questões sérias, dignas de atenção social. Para se relacionar `a escrita feminina, ela também utiliza a seguinte construção: "muito menos de propaganda, de expansão"; isto é, a escrita da mulher não tem utilidade no alargamento dos estudos literários, se tratando apenas de uma composição tolerável.

Já no desenlace inferimos que a cronista Irene Lisboa mostra um tom pessimista, cética de que viveria para ver uma sociedade mais justa e igualitária, entre homens e mulheres, ela também questiona por quanto tempo, perduraria esses princípios excludentes e androcêntricos. Mais à frente ela expõe que às mulheres que bem escrevem só resta serem lastimadas pela sociedade, por não terem nascido homens, uma vez que nesse contexto social, apenas os homens eram "presenteados com o dom da escrita".

$\mathrm{Na}$ gente bem intencionada continuará somente a persistir aquela bondosa pena de que certas mulheres não sejam homens! Porque aos homens é que é dado o pensamento e a acção. Às mulheres, a frivolidade. Frivolidade que se cultiva e se paga, beijando-lhes a mão (LISBOA, 1983, p. 209.) 
As construções semânticas e estilísticas presentes nesta crônica, revela o envolvimento crítico e sentimental da cronista com a penosa realidade do gênero feminino. No caso da crônica analisada, o envolvimento é, agudamente, pessoal, visto que ela sentia na própria pele a desconsideração de uma sociedade patriarcal, perante a arte literária de autoria feminina.

A mesma envoltura é percebida na crônica "A condição da mulher", de Rachel de Queiroz. No escrito, a cronista também apresenta um tom sentimental e crítico, posto que vivenciou o árduo destino de ser mulher no século XX. Logo no início da crônica é relatado a respeito da situação feminina, escravizada não só do ponto de vista social, mas também "fisiológico".

Consoante a escritora, o gênero feminino foi moldado para ocupar o lugar estabelecido pelos princípios disseminados pelo escopo social masculino. É o que observamos na seguinte passagem: "aliás no meu conceito, o problema não tem solução. O homem tem seus ócios garantidos pela natureza e nós somos escravas da carne. Livre dos compromissos que nos amarram pode ele se entregar à vontade à vida de espírito" (QUEIROZ, 1945, p. 122, grifos nossos.). Quer dizer, enquanto o homem tem as regalias, dias de repouso; momentos para refletirem. As mulheres são "escravas da carne"; uma locução adjetiva de categoria negativa, capaz de criar uma consistente expressividade, despertando questionamento entre os leitores dessa crônica. Um exemplo de questionamento seria: que destino cruel teriam as mulheres no século XX, que são caracterizadas como escravas da carne? Observemos que o homem alcança a vida de espírito, isto é, o nível da reflexão; já as mulheres estariam destinadas a ocupar apenas o nível carnal. Também percebemos que se tratam de adjetivos que enquadram a mulher em uma posição oposta ao do homem, quer dizer os adjetivos entregam a condição da mulher. De acordo com Murata (2008):

o adjetivo classificador refere-se à especificação de condições sociais, forma, cor, tamanho, que podem identificar os objetos/seres, enquanto o uso do não classificador de um adjetivo é, na realidade, uma avaliação de um objeto subjetivo. (MURATA, 2008, p. 301.) 
Ao que nos parece, a cronista Rachel de Queiroz busca expor como as determinações sociais impediram as mulheres de desenvolverem plenamente suas identidades, algo que, nessa época, apenas os homens conseguiam alcançar, porque possuíam momentos de ócio. Ao nosso ver, os vocábulos usados se adequam e expressam claramente a realidade feminina. É fundamental utilizar os lexemas apropriados para atingir a intencionalidade semântica e assim alcançar o objetivo do texto, perante o leitor. Como a própria Rachel de Queiroz explanou em uma crônica chamada "Vocaşão literária": "assim para escrever, para poetar, tem que haver essa coisa que lhe bota as letras na mão e as palavras na boca. As letras e as palavras certas" (QUEIROZ, 1957, p. 130). Já em outro excerto, é dito que,

\begin{abstract}
por mais inteligente que seja uma mulher, por mais que se enfronhe no campo mental masculino, sempre estará nele como uma estranha; e a dramática interrogação do SER ou não SER que para o homem representa a questão suprema, para ela não significa mais do que um jogo, que ela poderá jogar habilmente, se bem ensinada, mas que nunca lhe há de absorver. E ela se sentirá sempre consciente do convencionalismo daquele jogo, da sua frivolidade, da sua inutilidade (QUEIROZ, 1945, p. 122, grifos nossos.)
\end{abstract}

Ao que nos parece a falta de consideração à escrita de autoria feminina conduz a mulher à uma verdadeira crise existencial; embora tenha afeição pela arte da escrita, ela não sente que engloba o mundo literário. Tal situação a leva a se sentir uma "estranha", adjetivo que define claramente as mulheres que burlavam o sistema patriarcal e desenvolviam atividades vistas como destinadas aos homens; viver em tais circunstâncias às colocavam na condição de "excêntricas", "incomuns". O adjetivo "estranha", fixa o sentimento feminino no mundo composto para beneficiar os homens. A mulher era vista como uma esquisita, um ser que não se identifica com o que está posto no meio social. E perdendo-se em pensamentos sobre o que ela é ou poderia ser, acaba sendo repreendida pelas convenções sociais.

Do mesmo modo que Irene Lisboa em Portugal, Rachel de Queiroz também compreende que a escrita de autoria feminina, diante da sociedade patriarcal; infelizmente, era relacionada a "frivolidades"; nunca aos assuntos sérios da vida. As duas cronistas, durante 
o século 20, viveram os dissabores de ser uma mulher escritora em uma sociedade patriarcal. Ao final da crônica, Rachel de Queiroz diz:

se ela diz as verdades brutais da vida é uma virago, se não as diz não passa de uma boneca falante. $E$ se, num prodígio de equilíbrio consegue manter-se a igual distância de ambos esses abismos, e nada faz que peque por demais ou por de menos, o melhor que consegue é este elogio singular: "ESTA MULHER ESCREVE TÃO BEM QUE ATÉ PARECE UM HOMEM". (QUEIROZ, 1945, p. 118 grifos nossos.)

Nessa passagem evidenciamos alguns vocábulos utilizados para designar que perante o patriarcado, a mulher não possui o equilíbrio suficiente para realizar a arte da escrita. Lembramos também da ideia fantasiosa de que mulher é vista, socialmente, como um ser frenético. É uma "virago", mulher com aspectos masculinos, posto que não é característico à mulher falar de forma áspera, brutal; elas precisam expressar-se com docilidade. No entanto, quando a mulher não diz verdades em suas produções escritas, é vista como uma boneca falante. A adjetivação utilizada cria a imagem de uma sociedade imoderada e depreciativa em relação à figura feminina. Escancara-se, assim, a sujeição das mulheres que viviam aprisionadas ao escopo social e que impedia o reconhecimento de sua escrita.

\section{Considerações finais}

Com a análise das crônicas, notamos que as escritoras em muito se aproximam ao tratar da figura feminina. Mesmo estando distantes de maneira continental, elas criticaram e escancararam a realidade do sistema patriarcal. Foram corajosas, em uma época tão adversa ao gênero feminino. Essas cronistas utilizaram um gênero tão pouco prezado, como veículo de denúncia do sufocamento e silenciamento sofrido pelas mulheres. Com tom irônico, com adjetivos que descreviam, outros que classificavam a condição feminina; seja com um tom mais sentimental, ou revoltoso, elas não se calaram diante às injustiças sofridas, colaboraram de forma muito considerável pela transformação da condição feminina. Apesar das críticas negativas que Rachel de Queiroz vem sofrendo ao longo dos anos, não 
podemos negar que o seu trabalho literário muito contribuiu para que as mulheres da atualidade tivessem o espaço que muitas não tiveram no século anterior. Então, independentemente, de suas posições políticas, é preciso valorizar a sua obra, que é maior do que qualquer escolha que diz respeito às questões pessoais, políticas.

Rachel de Queiroz e Irene Lisboa demonstraram ao sistema dominado por homens que as mulheres escrevem sobre os mais variados assuntos que compõem a sociedade, e que a grande questão não está relacionada a capacidade intelectual da mulher, mas o silenciamento, a introversão que o patriarcado provoca ao gênero feminino. Nunca foi questão de capacidade, mas de sufocamento, e os que controlam a conjuntura social, possuem, evidentemente, consciência a esse respeito. Mas as cronistas não foram sufocadas pelo contexto, e por meio de um gênero pouco apreciado, as literatas conseguiram transgredir o quadro social em vigência. Tratamos de crônicas escritas no pretérito, entretanto essa é uma discussão que transcende as épocas.

\section{LA IMAGEN DE LA MUJER QUE ESCRIBE EN LAS CRÓNICAS DE RACHEL DE QUEIROZ E IRENE LISBOA}

RESUMEN: este artículo propone analizar la mirada crítica de las cronistas Rachel de Queiroz e Irene Lisboa sobre la representación de la mujer escritora, a través de sus crónicas, sin perder de vista el contexto vivido en Brasil y Portugal. Buscamos tratar a dos mujeres expresivas por la literatura de sus países y más allá; de un género no canónico, la crónica. Además de intentar encontrar las confluencias y, o divergencias de la representatividad femenina existente en la escritura de las dos escritoras, desde sus puntos de vista hasta el proceso de adjetivación. Utilizamos como base teórica conceptual del género literario Massaud Moisés (2007); Paula Lopes Cristina (2010); Davi Arrigucci (1987); Machado de Assis (1994) entre otros. Como aporte teórico sobre Rachel de Queiroz, utilizamos Hollanda (2005); Eduardo Assis (2005) y para Irene Lisboa utilizamos Paula Morão (1983), Óscar Lopes (1994) entre otros. Para analizar el proceso de adjetivación, utilizamos Bechara (2009) y Murata (2008). Estas cronistas aportaron mucho al campo literario, pero aún permanecen poco investigadas y como merecen deferencia, decidimos desarrollar esta investigación junto con el género poco estimado por las escuelas y la Academia.

PALABRAS-CLAVE: Crónica; Irene Lisboa; mujer escritora; Rachel de Queiroz. 


\section{REFERÊNCIAS}

ARRIGUCI, Davi. Enigma e comentário. São Paulo: Companhia das Letras, 1987.

ASSIS, Machado. Crônicas escolhidas de Machado de Assis. São Paulo: Ática, 1994.

CÂNDIDO, Antônio. A vida ao rés do chão. In: PARA GOSTAR de ler: crônicas. São

Paulo: Ática, 2003, v. 5, p. 89-90.

CASTELO, José. Crônica, um gênero brasileiro. Suplemento literário, setembro de 2007.

COVA, Anne; PINTO, Antônio Costa. O Salazarismo e as mulheres: uma abordagem comparativa. Penélope: revista de história e ciências sociais. Espanha: n. 17, p. 71-94, 1997.

DUARTE, Constância. Feminismo e literatura no Brasil. Revista Estudos Avançados. São Paulo: v. 17, n. 49, p. 151-172.

DUARTE, Eduardo de Assis. Literatura, politica, identidades: ensaios. Belo Horizonte: FALE/UFMG, 2005.

GUIMARÃES, Elina. A mulher portuguesa na legislação civil. Revista Análise social, Lisboa, v. 22, n. 92-93, p. 557-577, 1986.

HOLLANDA, Heloísa Buarque de. Rachel de Queiroz: Rio de Janeiro: Agir, 2005.

LISBOA, Irene. Folhas Soltas da Seara Nova. Lisboa: INCM, 1983.

LOPES, Paula Cristina. A crónica (nos jornais): O que foi? O que é? Biblioteca online de ciência e comunicação, 2010. Disponível em < http://www.bocc.ubi.pt/pag/bocccronicalopes.pdf $>$ Último acesso em 25 de novembro de 2019.

MASSAUD, Moisés. A Criação Literária: prosa II. 20. ed. São Paulo: Cultrix, 2007.

SÁ, Jorge. A crônica. 5. ed. São Paulo: Ática, 1997.

MORÃO, Paula; MAGALHÃES, Violante F. A Escrita de Irene. Lisboa: Munícipio de Arruda dos Vinho, 2007.

MURATA, Elza Kioko Nakayama Nenoki. Adjetivos: fio condutor da narrativa. Signótica. Goiás: v. 20, n. 2, p. 297-308, jul./dez. 2008.

Recebido em: 30/09/2020.

Aprovado em: 30/12/2020. 